\title{
THE EFFECT OF INDIVIDUAL AND SITUATIONAL FACTORS ON CAREER SATISFACTION AND AFFECTIVE COMMITMENT AMONG GENERATION Y EMPLOYEES: A CASE STUDY OF TELECOMMUNICATION COMPANY IN INDONESIA
}

\author{
Noviandri Prima Dewi \\ Department of Industrial and Organizational Psychology, Faculty of Psychology, \\ University of Airlangga, Surabaya, Indonesia \\ *E-mail: primadewinoviandri@gmail.com
}

\begin{abstract}
Since massive retirement occurs at this telecommunication company, it caused millennial employees to replace positions or positions previously occupied by generation $\mathrm{X}$. This resulted in generation $Y$ dominating the workforce and providing challenges for the company. On the other hand, the phenomenon that often occurs in millennials is a lack of commitment and not easily satisfied. Based from this phenomenon, this study examines the effect of individual factors (proactive personality \& performance goal orientation) and situational factors (organizational learning culture \& leader-member exchange) on career satisfaction and affective commitment among generation $\mathrm{Y}$ employees in telecommunication company. This study uses a quantitative approach and the data collection techniques used are by distributing questionnaires. The population of this study are 123 employees from generation $\mathrm{Y}$ employees. The technique of determining the sample in this study is purposive sampling and the data testing techniques were using PLS. The results of this study indicate that situational factors (organizational learning culture \& leader-member exchange) have a significant positive influences on career satisfaction and affective commitment. Meanwhile, the individual factors (proactive personality and performance goal orientation) have only a significant positive influences on career satisfaction. But on affective commitment, only proactive personality has a significant positive influence. Whereas the performance goal orientation does not significantly influence on affective commitment. This study also prove that there is a positive and significant influence between career satisfaction and affective commitment among generation $\mathrm{Y}$ employees in telecommunication company.
\end{abstract}

\section{KEY WORDS}

Generation Y, proactive personality, performance goal orientation, organizational learning culture, leader-member exchange, career satisfaction, affective commitment.

As the largest telecommunications and network services company in Indonesia, the company has a vision to "Be the king of digital in the region" and the mission is "Lead Indonesian digital innovation and globalization". In an effort to achieve this vision and mission, it is important for the company to realize the importance of building great leaders \& people. So that the obsession "to become a Global TOP 10 Telco in 2020" is achieved.

However, to achieve this, one of the branch offices is currently experiencing a phenomenon of massive retirement that has occurred since 2015 and its peak occurred in 2019-2021. This causes the company to experience employee regeneration on a large scale and resulted in generation $\mathrm{Y}$ dominating the workforce and providing challenges for the company.

The number of millennials that have dominated now needs to be adjusted so that this generation of employees can make maximum contributions. This generation needs proper handling because the character and way of working are not the same as the previous generation. $\mathrm{Ng}$ et al., (2012) state that millennials have lower career satisfaction levels compared to the previous three generations. This generation also shows a lower affective commitment and less willing to stay in the same organization compared to the previous generation ( $\mathrm{Ng}$ et al., 2012). 
Apart from the negative views of millennial generation, there are positive views that this generation has the ability with communication and technology, the ability to see problems and opportunities from a new perspective, and more comfortable working in teams (Myers and Sadaghiani, 2010; Howe and Strauss 2000; Gorman et al., 2004).

The advantage of this generation is that they have great potential that can contribute to the company, especially the way and the spirit of working. Therefore, the organization must strive to retain millennial employees in the company. These efforts can be done by increasing the career satisfaction and affective commitment of millennial employees.

According to Rhoades and Eisenberger (2001), affective commitment is a determinant of a person's loyalty employees of the organization. Employees who have affective commitment that can show a sense of belonging to the organization, increase involvement in the organization, a desire to achieve goals and a desire to maintain in the organization. Besides that, according to Joo and Park (2010), career satisfaction and affective commitment in the work environment can be influenced by various factors including personal and situational factors.

Factors that influence career satisfaction and affective commitment are based on career motivation theory by London (1983). This multidimensional model has three interrelated components: individual factors, situational factors, career decisions and behaviour. This model explains that personal factors are obtained based on individual behaviour such as proactive behaviour, and also obtained from individual goals such as goal orientation. Whereas situational factors are obtained based on the existence of various aspects related to the work environment. For examples leadership styles, learning cultures, compensation systems, company policies and rules, and changes in the work environment.

The first individual factor that became a predictor of career satisfaction and affective commitment in this study was proactive personality. Proactive personality is a belief in one's ability to overcome inhibition by situational forces and the ability to influence changes in the environment (Bateman and Crant, 1993). Park and Joo (2012) found that proactive personality has a significant relationship to career satisfaction.

The second individual factor which is a predictor of career satisfaction and affective commitment is performance goal orientation. Goal orientation is a goal that is pursued by each individual in a certain achievement (Park and Joo, 2010). There are two types of goal orientation, namely learning goal orientation and performance goal orientation (Park and Joo, 2010). Performance goal orientation has a significant influence on career satisfaction. A significant predictor of career satisfaction is goal orientation which includes social and material support to achieve employee goals (Barnett and Bradley, 2007). Several studies have shown that career satisfaction is always associated with goal orientation (Egan, 2005; Goodstalk and Sosik, 2003; Park and Joo, 2010; Joo and Ready, 2012; Park and Joo, 2013). When Park and Joo (2010) found that learning goal orientation with career satisfaction was not significant, then learning goal orientation was not mentioned in this study.

Performance goal orientation can positively influence career satisfaction (Park and Joo, 2010). Millennial employees who have high-performance goal orientation tend to produce good performance. So that, satisfaction is obtained when the employee gets positive appreciation from coworkers and their superiors. Robinson (2000) states performance goals orientation can affect affective commitment. High performance goal orientation employees show their best abilities and tend to want to be seen by organizations as employees who are highly committed to the company.

The first situational factor that predicts career satisfaction and affective commitment is the culture of organizational learning. Organizational learning culture refers to organizations that are skilled in creating, acquiring, transferring knowledge, and changing behaviour to reflect new knowledge and insights (Garvin, 1993). Based on previous research found that organizational learning culture can increase career satisfaction levels (Egan et al., 2004). Employees who get lessons from the organization they occupy will feel psychologically positive and satisfied with what is provided by the organization in achieving employee career satisfaction. Mathieu and Zajac (1990) stated that organizational learning culture can increase affective commitment. Organizational learning culture makes positive psychological 
feelings that felt by employees, employees feel cared by the organization when given insight and new knowledge to progress themselves to strengthen the desire to always be in the company.

The second situational factor that predicts career satisfaction and affective commitment is Leader-member exchange. Leader-member exchange is the quality of interpersonal exchange relationships between employees and their supervisors (Graen and Uhl-Bien, 1995). Han (2010) states that leader member exchange affect employee career satisfaction. Employee who has a good relationship (trust-based) with his boss, will easily get resources and basic information support from their superiors in achieving career satisfaction. Joo (2010) states there is a positive relationship between leader member exchange and affective commitment. Employees who have higher relationship quality will get greater support from the leader. So that the supported employee appears happy and makes himself feel like he wants to commit more to the company and his boss.

The purpose of this study was to determine the effect of personal factors (performance goal orientation \& proactive personality) and situational factors (organizational learning culture \& leader-member exchange) on career satisfaction and affective commitment. It is hoped that in this research, practitioners of human resources in this company can play a role important in increasing career satisfaction and employee commitment by implementing practices such as cultural change and leadership development using coaching or mentoring.

\section{LITERATURE REVIEW}

Career Motivation Theory. London (1983) defines career motivation as an incentive that arises from within a person (individual) and from the organizational environment to improve his abilities to achieve a better career. From this career motivation theory, there are two factors of individual proactive personality and performance goal orientation. Career motivation theory also explains the situational factors, including organizational learning culture and leader-member exchange.

Dimensions of individual factors are the variable needs, interests, and personality that is potentially relevant to one's career. It is also revealed that career motivation models can be linked to individual personalities and influenced by situational (contextual) conditions (London, 1983).

Proactive personality. According to Bateman and Crant quoted by Joo (2012), proactive personality can be said to be a belief in one's ability to overcome obstacles by situational (contextual) strength and the ability to influence environmental change. Individuals with proactive personality have a sense of curiosity about what happens to their environment and have confidence in the situation he will face. Individual with proactive personality will always look for opportunities, show their initiative, take action carefully, and be persuaded to achieve it by bringing a change (Bateman and Crant, 1993).

Performance Goal Orientation. This is one of the goal categories that is found by Dweck (1986). Performance goal orientation focuses on the ability and effort of employees who want to be shown to other employees. Joo and Ready (2012) said that performance goal orientation refers to the desire to show one's competence to others and receive positive evaluations from others. In other words, employees want to show their ability to work to be recognized by their colleagues that they are competent.

Situational (contextual) conditions factors that can influence an individual's motivation in achieving his career are organizational learning culture and leader-member exchange. Both factors are obtained from the organization to motivate individuals in a career as desired. London (1983) revealed that career motivation models can be related to individual personalities and influenced by situational (contextual) conditions.

Organizational Learning Culture. This theory is termed as an organization that is skilled in creating, acquiring, and transferring knowledge, and modifying employee behaviour to reflect new knowledge and insights (Garvin in Joo, 2012). The explanation can be said that the organization can analyze and process certain information. This ability can reflect employees to deal with new cognitive situations to improve employee performance. 
Leader Member Exchange. Leader member exchange is a reflection of the quality of personal relationships between superiors and subordinates (Uhl-Bien in Joo, 2012). A high leader-member exchange can create a warmer company atmosphere than a low leadermember exchange. Low-quality leader-member exchanges are defined as those that are limited to exchanges that occur according to the employment contract (Liden, 1997).

Career Satisfaction. Gattiker and Larwood (1988) define career satisfaction as an overall affective orientation of an individual towards his career and work role. Someone assesses career success through several indicators, including the development of new skills, a balance between life and work, challenges, and goals of employees (Gattiker and Larwood, 1988; Heslin, 2005).

Affective Commitment. Mercurio (2015) define that affective commitment can be represented as the core and the most powerful source in influencing individual behaviour and feelings, forming individual perceptions, and can mediate individual reactions to organizational transactions. Based on the findings of Allen and Meyer (1993), affective commitment has shown correlation strong with the desired results and the organization has encouraged this affective commitment to its employees.

Hypothesis:

$\mathrm{H} 1$ : Proactive personality has a positive influence on affective commitment;

H2: Performance goal orientation has a positive influence on affective commitment;

H3: Organizational learning culture has a positive influence on affective commitment;

$\mathrm{H} 4$ : Leader member exchange has a positive influence on affective commitment;

H5: Proactive personality has a positive influence on career satisfaction;

H6: Performance goal orientation has a positive influence on career satisfaction;

H7: Organizational learning culture has a positive influence on career satisfaction;

H8: Leader member exchange has a positive influence on career satisfaction;

H9: Career satisfaction has a positive influence on affective commitment.

The research model is shown in Figure 1.

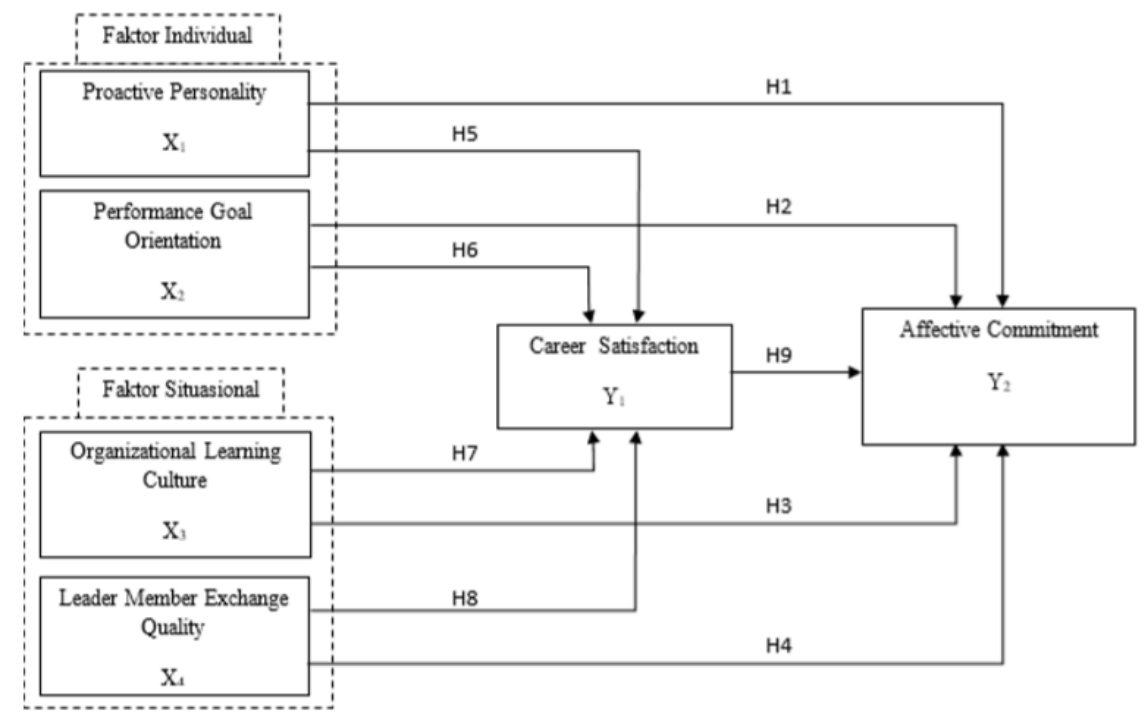

Figure 1 - Research Model

\section{METHODS OF RESEARCH}

This study uses a quantitative approach and the data collection techniques used are by distributing questionnaires. There are 123 generation y employees of the communication company who involved in this study to provide data to determine the effect of individual factors (proactive personality \& performance goal orientation) and situational factors (organizational learning culture \& leader-member exchange) on career satisfaction and affective commitment among generation y employees. The technique of determining the 
sample in this study used a purposive sampling technique and the data testing techniques used in this study were PLS.

\section{RESULTS AND DISCUSSION}

Based on PLS analysis, this study examines the effect of of individual factors and situational factors on career satisfaction and affective commitment among generation y employees.

$\mathrm{H} 1$ : Proactive personality has a positive and significant influence on affective commitment. The influence of proactive personality on affective commitment shows the calculation of path coefficient value to 0.187 , t-statistic of $2.387>1.64$. These statistical results prove that there is a positive and significant influence between proactive personality and affective commitment. Therefore, the research hypothesis which states that there is a significant influence between proactive personality and affective commitment is accepted.

This shows that proactive millennial employees are a form of affective commitment to this company. As explain by Gudermann (2010), if employees are involved in the opportunity to change the environment to get a benefit for employees and for the organization, it can affect the attachment of employees to the organization, because it will be a positive work experience. Thus, proactive employees can facilitate affective commitment (Thomas et al., 2010).

H2: Performance goal orientation has a positive influence on affective commitment. The influence of performance goal orientation on affective commitment shows the calculation of path coefficient value to 0.017 , t-statistic of $0.198<1.64$. These statistical results prove that there is no statistically proven positive and significant influence between performance goal orientation and affective commitment. Therefore, the research hypothesis which states that there is a significant influence between performance goal orientation and affective commitment is rejected.

This shows that generation y employees in this company who have a performance goal orientation are not strong enough to affect affective commitment directly. This study is in line with Park and Joo (2010) who found that performance goal orientation has a positive not significant relationship to affective commitment.

H3: Organizational learning culture has a positive influence on affective commitment. The influence of organizational learning culture on affective commitment shows the calculation of path coefficient value to 0,287 , t-statistic of $2,935>1,64$. These statistical results prove that there is a positive and significant influence between organizational learning culture and affective commitment. Therefore, the research hypothesis which states that there is a significant influence between organizational learning culture and affective commitment is accepted. This result is in line with Park and Joo (2010) who found that employees who felt the organization could maintain and support organizational learning, employees were inclined more committed in his organization (Joo, 2010).

$\mathrm{H} 4$ : Leader member exchange has a positive influence on affective commitment. The influence of leader member exchange on affective commitment shows the calculation of path coefficient value to 0,191 , t-statistic of $2,519>1,64$. These statistical results prove that there is a positive and significant influence between organizational learning culture and affective commitment. Therefore, the research hypothesis which states that there is a significant influence between leader member exchange and affective commitment is accepted.

This shows that millennial employees who feel the high-quality leader-member exchange in their work environment will increase their affective commitment. The importance of this support comes from research that reports strong commitment among employees who see alignment between their own goals and those of the organization (Reichers, 1986; Wayne et al. 1997; Vancouver \& Schmitt, 2006; Joo and Ready, 2012).

H5: Proactive personality has a positive and significant influence on career satisfaction. The influence of proactive personality on career satisfaction shows the calculation of path coefficient value to 0.287 , t-statistic of $3,568>1.64$. These statistical results prove that there is a positive and significant influence between proactive personality and career satisfaction. 
Therefore, the research hypothesis which states that there is a significant influence between proactive personality and career satisfaction is accepted.

This shows that millennial employees who have high proactivity in their work environment tend to feel higher career satisfaction as well. Like previous studies, an employees who have high proactive personality will affect their career satisfaction in their workplaces (Ng et al., 2005; Seibert et al., 2001; Bernett and Bradley, 2007; Joo and Ready, 2012).

H6: Performance goal orientation has a positive influence on career satisfaction. The influence of performance goal orientation on career satisfaction shows the calculation of path coefficient value to 0.308 , t-statistic of $3,663<1.64$. These statistical results prove that there is a positive and significant influence between performance goal orientation on career satisfaction. Therefore, the research hypothesis which states that there is a significant influence between performance goal orientation and career satisfaction is accepted.

This shows that millennial employees in this company who have high performance goal orientation will affect the satisfaction of their careers at work. The results of this study are in line with the opinion of Joo and Park (2010) which states that the performance goal orientation can positively influence employee career satisfaction when managers provide tasks or jobs that are appropriate to strengthen employee performance goal orientation.

$\mathrm{H7}$ : Organizational learning culture has a positive influence on career satisfaction. The influence of organizational learning culture on career satisfaction shows the calculation of path coefficient value to 0,172 , t-statistic of $2,004>1,64$. These statistical results prove that there is a positive and significant influence between organizational learning culture and career satisfaction. Therefore, the research hypothesis which states that there is a significant influence between organizational learning culture and career satisfaction is accepted.

This shows that millennial employees in this company feel the existence of organizational learning culture in their workplace that seems to have high career satisfaction. In accordance with the statement of Glisson and Durick (1988) which says that the more employees who use employee capabilities, the more satisfied employees are with their jobs. Culture for organizational learning can create opportunities for continuous learning, encourage collaboration and team learning, build systems for capturing and sharing learning, and use leaders who model and support learning at the individual, team and organizational level (Joo and Ready, 2012).

H8: Leader member exchange has a positive influence on career satisfaction. The influence of leader member exchange on career satisfaction shows the calculation of path coefficient value to 0,225 , t-statistic of $3,238>1,64$. These statistical results prove that there is a positive and significant influence between leader member exchange and career satisfaction. Therefore, the research hypothesis which states that there is a significant influence between leader member exchange and career satisfaction is accepted.

This shows that millennial employees in this company who feel the high-quality leadermember exchange, more feel the career satisfaction at work. According to Graen and UhlBien quoted by Han (2010) stated that when leader member exchange levels are high, employees tend to have a good relationship (trust-based) with their superiors. Employees likely to get resources and basic information support from their supervisors. Furthermore, the person may be satisfied with their supervisors because their supervisors can provide social support, to what extent the person is surrounded by other people who are sympathetic and caring (Noe et al., 2005).

H9: Career satisfaction has a positive influence on affective commitment. The influence of career satisfaction on affective commitment shows the calculation of path coefficient value to 0,225 , t-statistic of $3,238>1,64$. These statistical results prove that there is a positive and significant influence between career satisfaction and affective commitment. Therefore, the research hypothesis which states that there is a significant influence between career satisfaction and affective commitment is accepted.

This shows that millennial employees who feel career satisfaction directly can increase affective commitment to the company. This is in line with the statement of Igbaria and Greenhaus (1992) who say that employees who are satisfied with their careers can see 
greater benefits in maintaining membership in their organizations than employees whose careers are less satisfying. This study is also in line with the statements of Sattavorn (2018), Matahanankoon (2007), Igbaria and Greenhaus (1992) who find that career satisfaction has a significant effect on affective commitment.

\section{CONCLUSION}

Based on the previous discussion, it can be concluded that the career satisfaction of millennial employees in this company can be significantly influenced by individual factors (proactive personality, performance goal orientation) and situational factors (organizational learning culture, and leader-member exchange). This is in line with research conducted by Joo and Ready (2012) who found that proactive personality, performance goals orientation, organizational learning culture, and leader-member exchange can significantly influence career satisfaction.

The affective commitment of millennial employees in this company can be influenced by proactive personality, organizational learning culture, leader-member exchange, and career satisfaction. Whereas the performance goal orientation does not significantly influence affective commitment.

\section{REFERENCES}

1. Allen, N. J., \& Meyer, J. P. (1996). Affective, continuance, and normative commitment to the organization: An examination of construct validity. Journal of Vocational Behavior, 49(3), 252-276.

2. Barnett, B., \& Bradley, I. (2007). The impact of organizational support for career development on career satisfaction. Career Development International, 12 (7),617-636.

3. Bateman, T. S., \& Crant, J. M. (1993). The proactive component of organizational behavior: A measure and correlates. Journal of Organizarional Behavior, 14(2), 103-118.

4. Button, S.B., Mathieu, J.E. and Zajac, D. M. (1996). Goal orientation in organizational research: A conceptual and empirical foundation. Organizational behavior and human decision processes, 67(1), 26-48.

5. Dweck, C. S. (1986). Motivational processes affecting learning. American psychologist, 41(10), 1040.

6. Egan, T. M., Yang, B., \& Bartlett, K. R. (2004). The effects of organizational learning culture and job satisfaction on motivation to transfer learning and turnover intention. Human Resource Development Quarterly, 15(3), 279- 301. https://doi.org/10.1002/hrdq.1104.

7. Eisenberger \& Rhoades. (2001). Affective commitment to organization: The contributiuon of perceived organizational support. Journal of Applied Psychology. Vol. 86, 'No.5, 825836.

8. Garvin, D. A. (1993). Building a learning organization (Vol. 71, No. 4, pp. 7891). JulyAugust: Harvard Business Review.

9. Gattiker, U. E., \& Larwood, L. (1988). Managing technological development: strategic and human resources issues (No. 1). de Gruyter.

10. Graen, G., \& Uhl-Bien, M. (1995). Relationship based approach to leadership: development of leader-member exchange [LMX] theory of leadership over 25 years. Leadership Quarterly, 6(2), 219-247. https://doi.org/10.1016/10489843(95)90036-5.

11. Gorman, P., Nelson, T., \& Glassman, A. (2004). The Millennial generation: A strategic opportunity. Organizational Analysis, 12(3), 255-270.

12. Godshalk, V. M., \& Sosik, J. J. (2003). Aiming for career success: The role of learning goal orientation in mentoring relationships. Journal of Vocational Behavior, 63(3), 417437.

13. Gudermann, M. (2010). The relationship between proactive personality, affective commitment and the role of job stressors. 
14. Han, G. (2010). Trust and career satisfaction: The role of LMX. Career Development International, 15(5), 437-458. https://doi.org/10.1108/13620431011075321.

15. Heslin, Peter A. 2005. Conceptualizing and evaluating career success. Journal of Organizational Behavior, 113-136.

16. Howe, N., \& Strauss, W. (2009). Millennials rising: The next great generation. Vintage.

17. Joo, B. K., \& Park, S. (2010). Career satisfaction, organizational commitment, and turnover intention: The effects of goal orientation, organizational learning culture and developmental feedback. Leadership \& Organization Development Journal, 31(6), 482500.

18. Joo, B. K., \& Ready, K. J. (2012). Career satisfaction: The influences of proactive personality, performance goal orientation, organizational learning culture, and leadermember exchange quality. Career Development International, 17(3), 276-295.

19. Joo, B. K., Park, S., \& Oh, J. R. (2013). The effects of learning goal orientation, developmental needs awareness and self-directed learning on career satisfaction in the Korean public sector. Human Resource Development International, 16(3), 313-32.

20. Liden, R. C., \& Maslyn, J. M. (1998). Multidimensionality of leader-member exchange: An empirical assessment through scale development. Journal of management, 24(1), 43-72.

21. London, M. (1983). Toward a theory of career motivation. Academy of management review, 8(4), 620-630.

22. Mercurio, Z. A. (2015). Affective commitment as a core essence of organizational commitment: An integrative literature review. Human resource development review, 14(4), 389-414. https://doi.org/10.1177/1534484315603612.

23. Myers, K. K., \& Sadaghiani, K. (2010). Millennials in the workplace: A communication perspective on millennials' organizational relationships and performance. Journal of Business and Psychology, 25(2), 225-238.

24. Ng, T. W. H., Eby, L. T., Sorensen, K. L., \& Feldman, D. C. (2005). Predictors of objective and subjective career success: a meta-analysis. Personnel Psychology, 58, 367-408. https://doi.org/10.1016/S0378-7206(99)00004-X.

25. Ng, E., Lyons, S. T., \& Schweitzer, L. (Eds.). (2012). Managing the new workforce: International perspectives on the millennial generation. Edward Elgar Publishing.

26. Renee Barnett, B., \& Bradley, L. (2007). The impact of organisational support for career development on career satisfaction. Career Development International, 12(7), 617-636.

27. Robinson, J. M. (2000). Structural Determinants of Job Satisfaction and Organizational Commitment in Turnover Models, 9(4), 479-493.

28. Seibert, S. E., \& Kraimer, M. L. (2001). The five-factor model of personality and career success. Journal of vocational behavior, 58(1), 1-21.

29. Thomas, J. P., Whitman, D. S., \& Viswesvaran, C. (2010). Employee proactivity in organizations: A comparative meta-analysis of emergent proactive constructs. Journal of Occupational and Organizational Psychology, 83(2), 275-300. https://doi.org/10.1348/096317910X502359. 